\title{
Poverty Response to the Household Type of Elderly and Old-Age Pension
}

\author{
Andrews Doeh Agblobi ${ }^{1}$, Anthony Kofi Osei-Fosu ${ }^{2} \&$ Hadrat Yusif ${ }^{2}$ \\ ${ }^{1}$ Department of Banking \& Finance, University of Professional Studies, Accra \\ ${ }^{2}$ Department of Economics, Kwame Nkrumah University of Science and Technology, Kumasi \\ Correspondence: Andrews Doeh Agblobi, Department of Banking \& Finance, University of Professional Studies, \\ Accra
}

Received: November 29, 2020

Accepted: December 22, 2020 Online Published: December 29, 2020

doi:10.5430/bmr.v9n4p20

URL: https://doi.org/10.5430/bmr.v9n4p20

\begin{abstract}
This paper investigates the effect of household type and old-age pension on poverty in Ghana. Primary data was collected from households with the elderly across six Districts in the country. A binary logistic regression estimation was used for the analyses. The result shows that whereas there was 14.4 times probability of being poor by living in an elderly only household, there is a 2.2 times probability of being poor in a household of the elderly and working-age person. The findings also show that the probability of a pension recipient being poor was 0.143 times less likely as compared to those that were not. Thus, there was a significant negative relationship between receipt of old-age pension and poverty. The study recommends that public policy on old age poverty alleviation must include pension provisions while those that use basic salary should consider using gross salary for pension calculation.
\end{abstract}

Keywords: pensions, social security, poverty, elderly, households

\section{Introduction}

The financial benefits derived from the social security pension are used as a reliable source of income for households' consumption such as food, clothing and shelter. Hence, the lack of pension system could expose the elderly to severe hardship in their old age (Balco, Sebo, Mestan, \& Sebova, 2018; De la Torre Torres, Figueroa, \& Alvarez-Garcia, 2017; Bruce \& Turnovsky, 2013). On the average, the elderly in developing countries live among a four persons' size households that extends to three generations residencies (Jouste \& Rattenhuber, 2018). The provision of social pension offers more choice such as encourage retirement and whether or not to work at old age (Anku-Tsede, 2015; Barrientos, 2014).

The problem that individuals aged into poverty especially in the developing countries, including Ghana, may deter individuals who are gainfully employed, to aspire for retirement at the national retirement age of 60 years (Stewart \& Yermo, 2009). The low levels of salaries which results in low pension benefits for defined benefit schemes is part of the problem. This raises the concern whether recipients of the old-age pension could be among the poorest and also whether the type of household they live in could affect their poverty situation. Faye (2007) studies on poverty and pension were largely based in Senegal a country in West Africa and concluded that poverty is pervasive among elderly. Quartey, Kunawotor and Danquah (2016) who investigated sources of retirement income among formal sector workers in Ghana also found that pension and investment were among the least source of income for the elderly. As far as literature on pensions and poverty issues are concerned, very limited empirical studies on households with elderly in Ghana exist.

A study by Laryea, Andoh and Asuming (2019) on the role of pensions in poverty reduction in Ghana did not focus on households with elderly. Jouste and Rattenhuber (2018) studied on the role of universal pension made use of secondary source of national data that did not focus on the elderly residencies. This notwithstanding, the evidence with respect to Ghana is not conclusive in the literature and could be inadequate for policy formulation.

This study contributes by investigating the effect of household type and old-age pension on poverty and also determines the impact of an economic shock on poverty. Poverty is the arbitrary measure of annual income (or expenditure) equivalent of the monetary value of which several persons or households who are unable to earn (or spend) above the determined threshold within a period are classified as poor (Jouste \& Rattenhuber, 2018; GSS, 2018; Hulme \& Mckay, 2015). It is defined in Ghana as the value of consumption necessary to satisfy minimum subsistence needs of a household. By using an annual income equivalent of US\$23,500 in 2015, 15\% of the population of the United States 
of America were identified as poor (Mankiw, 2015). McNamara (1975:19) distinguished absolute and relative poverty by an account that absolute poverty relates to "income levels below which even minimum standards of nutrition, shelter and personal amenities cannot be maintained while relative reflects extreme differences in the level of living between the top and bottom strata of society." The consequences of poverty in developing countries include malnutrition, precarious access to water and the inability of the elderly to support their children or grandchildren's educational needs, and the lack of access to financial assets are attributes of poverty (Granlund \& Hochfeld, 2020).

Barrientos (2014); Kidd and Whitehouse (2009) observed that public pensions that reach the vast majority of older people have been effective in eliminating income poverty in old age in some countries such as the Czech Republic, the Netherlands and New Zealand. Kakwani and Subbarao (2005) studied 15 Sub-Saharan African (SSA) countries including Ghana and found that countries that do not have universal social pension have older persons that are poorer compared to those that have a social pension. They used household survey information of the various countries.

Jouste and Rattenhuber (2018) used a hypothetical microsimulation to introduce an old-age universal pension in Ecuador, Ghana, Tanzania and South Africa. They used each country's data and the established poverty lines in respective countries. They stated that in Ghana and Tanzania, the secondary data source question asked respondents about the amount of income they received and how often they get the income from their jobs. They found that in Ghana and Tanzania, poverty among the recipients fell as well as the entire population as they introduce old-age universal pension. These countries do not have universal pensions. For example, poverty fell by $24 \%$ and $33 \%$ in Ghana and Tanzania respectively. However, in Ecuador and South Africa that had mean-tested schemes, were dependent on the type of simulated implementations. In some instances, the poverty reduced while in others poverty increased in Ecuador. In South Africa, an experiment to abolish existing mean-tested pension and replaced it with a universal pension rather increased poverty. Even in cases where poverty reduced, it was $12 \%$ and $1.6 \%$ in Ecuador and South Africa respectively.

Laryea, Andoh and Asuming (2019) studied the role of the pension schemes in Ghana towards poverty reduction by drawing a comparison between pensioners' household and non-pensioners' households. They used secondary data from the sixth round of the Ghana Living Standard Survey. The authors used logistics regression to specified poverty as the dependent variable and other characteristics as independent variables. They found that difference in poverty for pensioners' and no pensioners' households was not significant. They attributed it to the small number of pensioners (105) as compared to a large number of non-pensioners' household $(16,667)$ that they used for the analyses.

A couple of things were missing in the above studies, especially in Laryea et al. (2019). The Ghana Living Standard Survey (GLSS) instrument specified question was about retirees and not pensioners. Some persons can retire but do not receive an old-age pension in Ghana. The Ghana Living Standard Survey did not collect data on pensioners neither non-pensioners' households of the elderly. It collected data under a classification called employment status and the poverty rates of households with a public employee, private employee, self-employed (non-agric and agric), unemployed and retired. Additionally, there was no specific question on pension in the instrument used by the Ghana Statistical Service for GLSS. At least the authors could have collected primary data to support the findings. Again, although the authors discuss issues about CAP30 pension, there was nowhere in their findings that included the type of pension that would have the highest impact on poverty.

Following the issues discussed so far, the question is what is the effect of household type and old-age pension on poverty in Ghana? What is the impact of an economic shock that shifts the poverty line on the households, all things being equal?

The paper is presented as follows: Section two explains method and materials, sample selection and data collection, model specification and estimation method. Section three discusses the results while Section four presents the conclusions.

\section{Method and Materials}

\subsection{Sample Selection and Data Collection}

The study employed a randomly sampled survey procedure to collect the data directly from the various household settings with elderly persons. A questionnaire was admitted through a semi-structured interview process to collect the data. The data on the household condition, whether or not an elderly receives a pension and personal characteristics as well as the geographical location was randomly collected across three regions: Upper East, Volta and Eastern regions. Within each of the three regions, two Districts were randomly selected. The six Districts that were selected were at different rates of poverty in the country. For instance, the Akatsi District had a poverty rate of $10.5 \%$ whereas Bulsa had a poverty rate of $56 \%$ of the entire population. Throughout this process, the probability proportional to population 
size was applied to take care of the urban-rural population distribution of the elderly. Using a formula, a sample size of 332 was obtained.

\subsection{Model Specification}

The type of household the elderly was living in, whether or not the elderly is a pension recipient, and personal characteristics, as well as geographical location, were identified as the explanatory variables in equation (1). The study adopted a moderation effect which is the indirect effect of old-age pension on poverty. The model in operational form is summarised as in equation 1 :

$$
y_{i}=f\left(H_{i} Z_{i} X_{i}\right)
$$

where $i$ denotes the number of elderly, $y$ represents the absolute poverty, $\mathrm{H}$ comprises of a demographic characteristic such as the household type, $\mathrm{Z}$ comprises of whether the elderly is a pension recipient or not variable; and $\mathrm{X}$ comprises of the personal characteristics and geographical location. A logit model to explain whether poverty among households with elderly is affected by the type of a household and old-age pension in a particular period as in equation (2) and (3) stated as follows:

$$
\begin{aligned}
P(\text { poverty }=1 / x)=G\left(\beta_{0}+\right. & \beta_{1} \text { eldperson }+\beta_{2} \text { eldchild }+\beta_{3} \text { eldworkage }+\beta_{4} \text { pen }+\beta_{5} \text { rural } \\
& +\beta_{6} \text { old }+\beta_{7} \text { oldold }+\beta_{8} \text { prim }+\beta_{9} \text { midjss }+\beta_{10} \text { sec }+\beta_{11} \text { post sec } \\
& \left.+\beta_{12} \text { deg ree }+\beta_{13} \text { gen }+\beta_{14} \text { remit }\right) \\
y_{i}= & \beta_{0}+\beta_{1} \text { eldperson }+\beta_{2} \text { eldchild }+\beta_{3} \text { eldworkage }+\beta_{4} \text { pen }+\beta_{5} \text { rural } \\
& +\beta_{6} \text { old }+\beta_{7} \text { oldold }+\beta_{8} \text { prim }+\beta_{9} \text { midjss }+\beta_{10} \mathrm{sec}+\beta_{11} \text { post } \mathrm{sec} \\
& +\beta_{12} \text { deg ree }+\beta_{13} \text { gen }+\beta_{14} \text { remit }+e
\end{aligned}
$$

where poverty is a binary response variable, eldperson is elderly person, eldchild is elderly and children, eldworkage is elderly and working age, pen is pension, rural is rural, old is old person, oldold is oldest of old, prim is a primary school, midjss is a middle school or Junior Secondary School, sec is secondary, post sec is post-secondary, degree is a degree or higher, gen is gender and remit is remittance. The $e$ represents the error term reflecting unobserved factors omitted from the model at 5 per cent.

\subsubsection{Dependent Variable}

The dependent variable is specified as a logistic function as in equation (4) and (5) follows:

$$
G\left(y_{i}\right)=\left[\frac{\exp \left(y_{i}\right)}{1+\exp \left(y_{i}\right)}\right]
$$

Therefore,

$$
\log \frac{G\left(y_{i}\right)}{1-G\left(y_{i}\right)}=y_{i}
$$

where $G\left(y_{j}\right)$ represents the nonlinear function of poverty that has a probability of between zero and one. The $y_{i}$ represents household with elderly whose total expenditure is below the poverty line and described as poor. Thus, $\exp \left(y_{i}\right)$ represents the likelihood that a household is poor while $1+\exp \left(y_{i}\right)$ represents a likelihood that a household is non-poor. As poverty is a binary response, the usual method used for nonlinear regression such as logit or probit could be used. This paper chose logit to probit because the error term of the logit function takes on cumulative distribution function a standard logistic function. However, the error term of the probit takes on the standard normal cumulative distribution function. The qualitative nature of the poverty variable necessitated the use of a dummy. The estimated national absolute poverty line of GHc 1,314.00 per annum (or GHc 110.00 per month) was adopted for the study (GSS, 2014). By this measurement, a household with elderly that has a total monthly expenditure that is below GHc110.00 was classified as poor and coded as 1 and 0 otherwise. 


\subsubsection{Independent Variables}

The independent variables of the study are the household type and old-age pension. The choice of the explanatory variables was based on literature and the variable importance to the explained variable, poverty. The variable for the household type that the elderly reside was categorised into three dummies such as elderly only, elderly and children, and elderly and working-age person. The elderly persons only measure a household with either only one or two persons aged 60 years or older. The elderly and children measure a household with at least one-person age 60 years or older and at least one person aged between zero and 14 years. The elderly and working-age measure a household with at least one person aged 60 or older and at least one other person aged between 15 and 59 years.

Old-age pension measures a household with elderly that receives a monthly pension as equal to one and zero otherwise. There are three major types of public pension schemes that provide qualified retirees old-age pension in Ghana. They are the SSNIT pension, CAP30 pension and Ghana Universities Superannuation scheme. A retiree in Ghana can be a recipient of any one of these three schemes.

\subsubsection{Control Variables}

A number of other variables that have effect on poverty were specified as dummy variables except for remittance that was a continuous variable. For instance, the localities that the elderly and their households reside was divided into urban and rural. This was also grouped into two with the rural localities made as a variable of interest. For example, rural equal to one if the elderly person resides in the rural locality or zero otherwise. The variable age was also divided into three different groups such as young old (between 60 and 74 years), old (between 75 and 84 years), and oldest-old (above 85 years) as suggested by (Neugarten \& Daton, 1973). Each of this age category was made to be a group of interest $(\mathrm{Yes}=1)$ and others made zero $(\mathrm{No}=0)$. The young-old was made as the reference variable. Old equal to one, is the elderly persons aged between 74 and 84 years, or zero otherwise. Oldest-old equal to one, if the elderly person is aged 85 years and above or zero otherwise. The variable education was also divided into a six Likert scale question with each made as a group of interest $(\mathrm{Yes}=1)$ and others zero $(\mathrm{No}=0)$. The variable of never been to school group was made as the reference and the others were made as variables of interest. The dummy variable prim equal to one if the last level of educational attainment of the elderly persons was primary school or zero otherwise; midjss is a dummy variable equal to one if the last level of education was middle school or Junior Secondary school or zero otherwise; sec is a dummy variable equal to one if the last level of education is a secondary school or zero otherwise; postsec is a dummy variable equal to one if the last level of education is a postsecondary school or zero otherwise; degree is a dummy variable equal to one if the last level of education is a degree or zero otherwise; gen is a dummy variable equal to one if individual sex was a male or zero otherwise. The remittance was continuous variables that measure the nominal amount of money received by an elderly in a particular period.

\subsection{Estimation Method}

To estimate the nonlinear binary response of poverty that was poor equal one, or nonpoor equal zero, the paper employed maximum likelihood estimation. The ordinary least squares or weighted least squares were not applicable for the nonlinear nature of binary regression variables (Negi \& Wooldridge, 2020). With the maximum likelihood estimations, the odds ratio was used. With the analysis of the odd ratio, a number below one shows a negative relationship and above one is positive. Thus, a negative effect on poverty must be interpreted as lowering of poverty.

\section{Result and Discussions}

Table 1 presents the finding of the household type and old-age pension on poverty. To investigate the effect of household type and old-age pension on poverty, equation (3) was estimated. The results obtained from the logistic regression show that the odds are such that living in a household with elderly persons only was highly likely of being poor by approximately 14.4 times as compared to living in another household type. Again, the odds of living in a household with an elderly and a child was highly likely of being poor by 13.7 times as compared to those that were not. These results show a positive relationship between households' type with the elderly and poverty.

Again, in table 1, the result shows that the odds that living in a household with the elderly as a recipient of old-age pension was less likely of being poor by 0.143 times as compared to those that were not. This result shows that there is a negative relationship between receipt of pension and poverty. The old-age pension that is paid to recipients is a critical source of income to the elderly monthly. This income is expected to improve the welfare of the household and lift them above the poverty line. From the sampled households, the average monthly pension was GHc476.60 with the highest amount as GHc 1,220.00 per month and the lowest as GHc20.00 per month. These monthly pension incomes were above the established monthly national poverty line of GHc 110.00 . 
This finding is supported by Jouste and Rattenhuber (2018); Kidd and Whitehouse (2009) and Franco et al. (2008) that households with elderly recipients of pension are less likely to be poor. Again, the results are consistent with the findings of Barrientos (2014) that a recipient of pension benefit is less likely to experience old-age poverty.

Table 1. Effects of household type and pension on poverty

\begin{tabular}{lllll}
\hline Independent Variables & Coefficient & Standard error & Odds ratio & p-value \\
\hline Constant & 19.516 & 8213.070 & 298908654.489 & 0.998 \\
Recipient pension & -1.942 & 0.607 & 0.143 & 0.001 \\
Elderly persons only & 2.670 & 0.439 & 14.434 & 0.000 \\
Elderly \& children & 2.593 & 0.521 & 13.371 & 0.000 \\
Elderly \& working age & 1.116 & 0.354 & 3.054 & 0.002 \\
Rural & 1.040 & 0.317 & 2.829 & 0.001 \\
Age old & 0.210 & 0.369 & 1.233 & 0.570 \\
Oldest old & -0.020 & 0.415 & 0.980 & 0.962 \\
Primary & -0.202 & 0.407 & 0.817 & 0.620 \\
Middle/JSS & -1.138 & 0.416 & 0.320 & 0.006 \\
Secondary & -1.539 & 0.908 & 0.215 & 0.090 \\
Post-Secondary & -1.291 & 1.199 & 0.275 & 0.282 \\
Higher & -19.773 & 8213.069 & 0.000 & 0.998 \\
Gender & -0.056 & 0.312 & 0.945 & 0.857 \\
Remittance & 0.032 & 0.336 & 1.033 & 0.923 \\
\hline Source: Adhos & &
\end{tabular}

Source: Authors calculation.

Estimation method: ML.Logit. Dependent variable = Poverty rate, No. Obs. 332. Overall percentage predicted is 78.5 .

With the finding that elderly persons who are pension recipients' lower households' poverty contrary to households with elderly who are not pension recipients, the economic intuition behind this is that households with the elderly that are non-recipients of pension are burdened by the presence of the elderly who are without any form of regular income. The finding confirms Faye (2007) results that there is a high correlation between poverty and elderly persons in households of most African countries and supports UN (2015) claim that many age into poverty in Africa which is due to the large number of the elderly population who do not receive a pension.

The geographical location such as the rural localities was used as a control variable and the result showed that a household with elderly living in the rural locality was 2.829 times more likely of being poor compared to those that were not. After the further division of the variable education, the findings showed that households with elderly who had attended formal education were less likely to be poor. For instance, households with elderly persons who had attained up to Middle School or Junior Secondary School lower households' poverty by 0.320 times compared to others. The results were statistically significant.

The implication is that educational achievement itself is likely to lower poverty. Intuitively, acquiring formal education enhances a person's job prospects that lead to a higher standard of living. Therefore, it is expected that educational attainment should lower old-age poverty.

\subsection{The Shock on the Poverty Line}

The findings obtained through sensitivity analysis to investigate a knock-on effect of an economic shock on the fixed poverty line shows that all things being equal if the independent variables were held unchanged, an economic shock that increases the poverty line to GHc 140.00 per month from the current level of GHS110 per month, would worsen the average poverty situation from 43.8 per cent to 48.2 per cent. Whereas, a shock that lowers the poverty line to GHc 80.00 per month would lower the overall poverty rate drastically to 27.1 per cent. 
Table 2 presents the logistic regression results of an economic shock to the poverty line. The regression estimates obtained increased the poverty among the households with elderly persons only; and elderly and children to 74.7 and 23.6 respectively. This implies that should there be a sudden unexpected upward change in the poverty line, all things being equal, the number of households below the poverty line will increase. The effect of pension benefits on households with pensioners was also high. This confirms Dartano (2011) findings that supposed the fixed poverty line should float, the poverty situation could be a lot worst which was the case in this analyses. The findings imply that any adverse situation that worsens the poverty level would affect households with elderly only, and elderly and children more than other groups.

Table 2. Shock on the poverty line

\begin{tabular}{lllll}
\hline Independent variable & Coefficient & Standard error & Odds ratio & P-values \\
\hline Constant & -2.821 & 3.053 & 0.060 & 0.355 \\
Elderly persons only & 4.314 & 0.759 & 74.749 & 0.000 \\
Elderly \& Children & 3.162 & 0.704 & 23.613 & 0.000 \\
Elderly \& Working Age & 0.992 & 0.448 & 2.698 & 0.027 \\
Pension recipient & -3.900 & 0.942 & 0.020 & 0.000 \\
Rural & 0.889 & 0.400 & 2.432 & 0.026 \\
Age old & 0.323 & 0.476 & 1.381 & 0.497 \\
Oldest old age & 0.328 & 0.491 & 1.388 & 0.503 \\
Primary & 0.306 & 0.530 & 1.358 & 0.564 \\
Middle School or JSS & -1.366 & 0.610 & 0.250 & 0.023 \\
Secondary & -1.525 & 1.115 & 0.218 & 0.171 \\
Post-Secondary & -0.148 & 1.366 & 0.863 & 0.914 \\
Higher or degree & 0.534 & 1.356 & 1.706 & 0.694 \\
Gender & 0.367 & 0.437 & 1.444 & 0.401 \\
Remittance & -0.001 & 0.001 & 0.999 & 0.125 \\
\hline Soure: Aut & & &
\end{tabular}

Source: Author's estimates.

Logit. Dependent variable $=$ Poverty rate. No. Obs. 332. Overall percentage predicted is $79.4 \%$.

\subsection{Results of Variance Inflation Test for Multicollinearity and Heteroscedasticity Test}

Table 3 shows the diagnostic result obtained from the conducted of multicollinearity test on the logistic regression. Table 3 mean variance inflation test (VIF) of the multicollinearity test result was 1.41 . This indicates that there were no multicollinearity symptoms with the multiple independent variables that were used to conduct the study.

Table 3. Results of Variance Inflation Test for Multicollinearity

\begin{tabular}{lll}
\hline \multirow{2}{*}{ Independent variables } & Collinearity Statistics & \\
\cline { 2 - 3 } & Tolerance & VIF \\
\hline Elderly persons only & 0.845 & 1.183 \\
Elderly \& Children & 0.868 & 1.152 \\
Elderly \& Working Age & 0.825 & 1.212 \\
Recipient of pension & 0.429 & 2.332 \\
Lives in the rural area & 0.881 & 1.136 \\
Age old & 0.790 & 1.265 \\
Oldest_old & 0.761 & 1.313 \\
Primary & 0.797 & 1.255 \\
\hline
\end{tabular}




\begin{tabular}{llc}
\hline Middle/JSS & 0.605 & 1.654 \\
Secondary & 0.689 & 1.451 \\
Post-Secondary & 0.766 & 1.306 \\
Higher & 0.553 & 1.808 \\
Gender & 0.756 & 1.323 \\
Remittance & 0.688 & 1.454 \\
\hline Mean VIF & & $\mathbf{1 . 4 1 0}$ \\
\hline
\end{tabular}

a. Dependent Variable: poverty.

Source: Author's Estimates.

The heteroscedasticity test that was conducted on the logistic regression also shows that the values of the variables were significantly greater than 0.5 . This therefore indicates that there is no heteroscedasticity problem with the estimation that was done. Other diagnostic statistics such as the Hosmer and Lemeshow test, Wald test and Chi-square were all fine.

\section{Conclusions}

The objective of this paper was to investigate the effects of household type and old-age pension on poverty in Ghana. Poverty as a monetary index which was based on absolute poverty line of GHc1, 314 per annum (or GHc 110 per month) was adopted in the study. The findings from the sampled households with elderly across three regions with six Districts localities show that social security pension lowers poverty and is consistent with theory. Thus, a recipient of pension benefit is less likely of being poor within the sampled localities.

As a policy recommendation, the Government should reform the pension system to allow the contribution rate and benefit payment to be on the gross salary. The Government should also consider introducing a pension system that covers the majority that may not be covered by the existing pension schemes. Effort should also be made to bridge the rural-urban gap of development challenges by ensuring the people in the rural areas get part of the scarce national resources.

\section{References}

Anku-Tsede, O., Amertowo, A., \& Amankwa, A. (2015). Managing Pension Funds in Ghana: Overview. Business and Management Research, 4(1), 25-33. https://doi.org/10.5430/bmr.v4n1p25

Balco, M., Sebo, J., Mestan, M., \& Sebova, L. (2018). Application of the Lifecycle Theory in Slovak Pension Syetem. Ekonomicky casopis, 66(1), 64 -80.

Barrientos, A. (2014). Is There a Role for Social Pension in Asia? Asia \& The Pacific Policy Studies, $2(1), 8-20$. https://doi.org/10.1002/app5.63

Bruce, N., \& Turnovsky, S. J. (2013). Social security, growth, and welfare in overlapping generations economies with or without annuities. Journal of Public Economics, 101, 12-24. https://doi.org/10.1016/j.jpubeco.2013.02.007

Dartano, T. (2011). Does Choice between an Endogenous and a Fixed Poverty Line Affect the Poverty Outcome of Policy Reform? Modern Economy, 2(1), 667-673. https://doi.org/10.4236/me.2011.24074

De la Torre Torres, O. V., Figueroa, E. G., \& Alvarez-Garcia, J. (2017). The Cost of homogeneity in life cycle pension funds: An explanation demand's inelasticity of Mexican pension funds with a performance attribution test. Eurepoan Research on Management and Business Economics, 22(3), p.117-126.

Faye, O. (2007). Basic Pensions and Poverty Reduction in Sub-Saharan Africa. CREPP.

Franco, D., Marino, R. M., \& Tommasino, P. (2008). Pension Policy and Poverty in Italy: Recent Development and New Priorities. Giorrale degli Economists Amali di Economia., 67(No. 2 (Luglio 2008)), 119-159.

Government of Ghana. (2008). National Pension Act (Act.766). Accra: Assembly Press.

Granlund, S., \& Hochfeld, T. (2020). That Child Support Grant gives Me Powers' -Exploring Social and Relational Aspects of Cash Transfer in South Africa in Times of livelihood Change. The Journal of Development Studies, 56(6), 1230-1244. https://doi.org/10.1080/00220388.2019.1650170 
GSS. (2018). Poverty Trends in Ghana (2005 - 2017). Ghana Living Standard Survey Round 7 (GLSS7). Accra: Ghana Statistical Service.

GSS. (2014). Poverty Profile in Ghana (2005 - 2013). Ghana Living Standard Survey Round 6 (GLSS6). Accra: Ghana Statistical Service.

Hulme, D., \& Mckay, A. (2015). Identifying \& Measuring Chronic Poverty: Beyond and Monetary Measure. In N. Kakwani, \& J. Silber, The Many Dimensions of Poverty. London: Palgrave Macmilan (p. 187-214). https://doi.org/10.1057/9780230592407_10

Jouste, M., \& Rattenhuber, P. (2018). A role for universla pension? Simulating universal pensions in Ecuador, Ghana, Tanzania and South Africa (WIDER Working Paper, No.2018/23, ISBN 978-92-9256-465-0, The United Nations University World Institute for Development Economics Research (UNU-WIDER), Helsinki). http://dx.doi.org/10.35188/UNU-WIDER/2018/465-0

Kakwani, N., \& Subbarao, K. (2005). Ageing and Poverty in Africa: the roel of Social Pensions. UNDP International Poverty Centre. WP No. 8. p.1-41.

Kidd, S., \& Whitehouse, E. (2009). Pensions and Old Age Poverty. In C. 3, Closing the Coverage Gap: Role of Social Pension and Other Retirement Income (p. 41-56).

Laryea, Margret Momo; Andoh, Charles and Asuming, Patrick (2019). The Role of Pensions in Poverty Reduction in Ghana. African Journal of Governance and Development, 8(1), 5-23.

Mankiw, N. G. (2015). Principles of Economics (7th ed.). USA: Cengage Learning.

McNamara, R. S. (1975). The Assault on World Poverty. Problems of Rural Development, Eduaction and Health. Baltimore and London: The John Hopkins University Press.

Negi, A., \& Wooldridge, J. M. (2020). Revisiting regression adjustment in experiments with heterogeneous treatment effects. Econometric Reviews. https://doi.org/10.1080/07474938.2020.1824732

Neugarten, B. L., \& Daton, N. (1973). Sociolofical Perspectves on the Life Cycle. In P. \&. Balters, Life Span Development Psychology: Personality and Socialisation. New York: Academic Press. https://doi.org/10.1016/B978-0-12-077150-9.50009-5

Quartey, P., Kunawotor, M. E., \& Danquah, M. (2016). Sources of retirement income among formal sector workers in Ghana. African Journal of Economic and Management Studies, 7(3), 366-378. https://doi.org/10.1108/AJEMS-07-2014-0054

Stewart, F., \& Yermo, J. (2009). Pension in Africa. Organisation for Economic Cooperation and Development Working Paper on Insurance and Private Pensions. Paris, oecd. Retrieved from: http://www.oecd.org/financial/private-pensions/42052117.pdf

UN. (2015). World Population Ageing 2015. Economic and Social Affairs. New York: United Nations.

\section{Copyrights}

Copyright for this article is retained by the author(s), with first publication rights granted to the journal.

This is an open-access article distributed under the terms and conditions of the Creative Commons Attribution license (http://creativecommons.org/licenses/by/4.0/). 